\title{
Net ecosystem carbon exchange in three contrasting Mediterranean ecosystems - the effect of drought
}

\author{
J. S. Pereira ${ }^{1}$, J. A. Mateus ${ }^{2}$, L. M. Aires ${ }^{3}$, G. Pita ${ }^{2}$, C. Pio ${ }^{3}$, J. S. David ${ }^{1}$, V. Andrade ${ }^{1}$, J. Banza ${ }^{1}$, T. S. David ${ }^{4}$, \\ T. A. Paço ${ }^{1}$, and A. Rodrigues ${ }^{4}$ \\ ${ }^{1}$ Instituto Superior de Agronomia, Universidade Técnica de Lisboa, Tapada da Ajuda, 1349-017 Lisboa, Portugal \\ ${ }^{2}$ Instituto Superior Técnico, Universidade Técnica de Lisboa, Av. Rovisco Pais, 1049-001 Lisboa, Portugal \\ ${ }^{3}$ CESAM \& Department of Environment, University of Aveiro, 3810-193 Aveiro, Portugal \\ ${ }^{4}$ Estação Florestal Nacional, Quinta do Marquês, 2780-159 Oeiras, Portugal
}

Received: 13 April 2007 - Published in Biogeosciences Discuss.: 12 June 2007

Revised: 8 August 2007 - Accepted: 17 September 2007 - Published: 28 September 2007

\begin{abstract}
Droughts reduce gross primary production (GPP) and ecosystem respiration (Reco), contributing to most of the inter-annual variability in terrestrial carbon sequestration. In seasonally dry climates (Mediterranean), droughts result from reductions in annual rainfall and changes in rain seasonality. We compared carbon fluxes measured by the eddy covariance technique in three contrasting ecosystems in southern Portugal: an evergreen oak woodland (savannah-like) with ca. $21 \%$ tree crown cover, a grassland dominated by herbaceous annuals and a coppiced short-rotation eucalyptus plantation. During the experimental period (2003-2006) the eucalyptus plantation was always the strongest sink for carbon: net ecosystem exchange rate (NEE) between -861 and $-399 \mathrm{~g} \mathrm{C} \mathrm{m}^{-2}$ year $^{-1}$. The oak woodland and the grassland were much weaker sinks for carbon: NEE varied in the oak woodland between -140 and $-28 \mathrm{~g} \mathrm{C} \mathrm{m}^{-2}$ year $^{-1}$ and in the grassland between -190 and $+49 \mathrm{~g} \mathrm{C} \mathrm{m}^{-2}$ year $^{-1}$. The eucalyptus stand had higher GPP and a lower proportion of GPP spent in respiration than the other systems. The higher GPP resulted from high leaf area duration (LAD), as a surrogate for the photosynthetic photon flux density absorbed by the canopy. The eucalyptus had also higher rain use efficiency (GPP per unit of rain volume) and light use efficiency (the daily GPP per unit incident photosynthetic photon flux density) than the other two ecosystems. The effects of a severe drought could be evaluated during the hydrological-year (i.e., from October to September) of 2004-2005. Between October 2004 and June 2005 the precipitation was only $40 \%$ of the long-term average. In 2004-2005 all ecosystems had GPP lower than in wetter years and carbon sequestration was strongly restricted (less negative NEE). The grassland was a net source of carbon dioxide $\left(+49 \mathrm{~g} \mathrm{C} \mathrm{m}^{-2}\right.$ year $\left.^{-1}\right)$. In the
\end{abstract}

Correspondence to: J. S. Pereira

(jspereira@isa.utl.pt) oak woodland a large proportion of GPP resulted from carbon assimilated by its annual vegetation component, which was strongly affected by the shortage of rain in winter. Overall, severe drought affected more GPP than Reco leading to the deterioration of NEE. Although the rain-use efficiency of the eucalyptus plantation increased in the dry year, this was not the case of evergreen oak woodland, which rainuse efficiency was not influenced by drought. Recovery after drought alleviation, i.e., beginning with heavy rain in October 2005, was fully accomplished in 2006 in the oak woodland and grassland, but slow in the eucalyptus plantation.

\section{Introduction}

The accounting of biological carbon sequestration requires adequate knowledge of inter and intra-annual variation in ecosystem carbon exchange with the atmosphere. Droughts are the main source of inter-annual variation in terrestrial carbon sequestration as they cause large reductions in gross primary productivity (GPP) as well as in net ecosystem exchange (NEE) of terrestrial ecosystems (Ciais et al., 2005; Granier et al., 2007; Pereira et al., 2006). Although this is true for most terrestrial biomes, it is especially relevant in seasonally dry climates where there is often a great variability in precipitation. The Mediterranean climate has a marked seasonality with a dry and hot summer, when low precipitation is coupled to high atmospheric evaporative demand, leading to a decrease in moisture availability to plants. In these climates, plant life cycles are tuned to rain periodicity. If the dry season lasts too long plant water deficits may negatively affect the capacity for carbon assimilation as a result of lower photosynthetic rates and leaf areas (or shorter life span of annual plants) induced by water stress. In recent

Published by Copernicus Publications on behalf of the European Geosciences Union. 
years, both the shape of the seasonal cycle of precipitation and the frequency of droughts changed dramatically in western Iberia, namely in Portugal (Paredes et al., 2006).

The objective of this work was the comparison of the interand intra-annual patterns of variation in the carbon balance of three ecosystems with contrasting vegetation, structure, phenology and management, under the same climate, in southern Portugal. The analysis was based upon several years of continuous eddy covariance measurements of carbon fluxes. We analysed the data on the basis of hydrological-years, i.e., the period between 1 October and 30 September of the following year, instead of normal calendar years, because it reproduces better the climate and the plant life cycle in the Mediterranean region and their inter-annual variability: germination of annuals in autumn, fast growth of herbage and tree flushing in spring, slowdown of biological activity in summer.

The ecosystems studied - the evergreen oak woodland (savannah-like) with scattered trees and a herbaceous groundlayer, the Mediterranean grassland dominated by $\mathrm{C} 3$ annuals and the coppiced short-rotation eucalyptus plantation - are typical components of the regional landscape, which consists of a highly humanized mosaic of different ecosystems typical of southern Europe. The evergreen oak woodlands are widely distributed in the Iberian Peninsula, as well as in other areas with Mediterranean climate, e.g., in parts of California (Baldocchi et al., 2004). In the Iberian Peninsula, large areas of these woodlands form a multipleuse agroforestry system, called montado in Portugal and dehesa in Spain. They cover approximately $33 \%$ of Portuguese forest area or $13 \%$ of non-urban area.The other two types are also representative, with grasslands covering $21 \%$ of non urban area and the coppiced eucalyptus plantations $8 \%$ of non urban area (19\% of forest area) in Portugal (country area $92391 \mathrm{~km}, 5 \%$ of which is urban).

Understanding the sensitivity of ecosystem carbon balance to drought has been one of the main challenges over the past few years. The most likely future climate scenarios for the western and central regions of the Iberian Peninsula point towards a longer dry season, with a strong negative rain anomaly in spring-summer and a positive anomaly in autumn (Miranda et al., 2006). A decrease in March precipitation is already going on since the early 1960's (Paredes et al., 2006). Moreover, annual rainfall is highly variable in the Mediterranean leading to frequent droughts (Xoplaki et al., 2004). Since the 1970s, the frequency of droughts, i.e., years with water shortage that negatively interfered with ecosystem processes, increased significantly in Portugal (Miranda et al., 2006). Due to climate variability, it was possible to access the impact of an outstanding dry spell (2004 and 2005) vis-à-vis years of "normal" rainfall (2003 and 2006). The 2004-2005 hydrological-year was characterized by extreme dry weather over most of Western Europe. The southern half of Iberia received roughly $40 \%$ of the usual precipitation between October 2004 and June 2005. This was the driest episode in the last 140 years, with negative impacts on agri- culture and natural ecosystems, in both, Portugal and Spain (Garcia-Herrera et al., 2007). The contrasting characteristics of the three ecosystems and the occurrence of this outstanding drought, provided a good framework to better understand the effects of drought on ecosystem carbon balance.

\section{Materials and methods}

\subsection{Site description, climate and vegetation}

This study is part of the CarboEurope-IP project. The experimental sites (Table 1) are in the same region of Portugal, approximately at $38^{\circ}$ latitude $\mathrm{N}$ and $8^{\circ}$ longitude $\mathrm{W}$. The sites of Mitra and Tojal, evergreen oak woodland and grassland, respectively, are located at short distance $(8 \mathrm{~km})$ from each other, near Évora, and the Espirra station, eucalyptus plantation, is near the town of Pegões, $63 \mathrm{~km}$ approximately northwest from Évora. The climate is typically Mediterranean, with a hot and dry summer. More than $80 \%$ of annual precipitation occurs between October and April. The long-term (1961-1990) mean annual temperature was $15-16^{\circ} \mathrm{C}$ and average annual precipitation ca. $669 \mathrm{~mm}$ for Évora (montado and grassland) and $709 \mathrm{~mm}$ for Pegões (Espirra; eucalyptus plantation). The Mitra station is on the "Alentejana" plain, with low altitude (220-250 m) and gentle slopes with soils derived from granite rock. It is in the middle of a homogeneous landscape dominated by evergreen oak savannah-like woodlands with Quercus ilex ssp. rotundifolia and Quercus suber trees. The understorey consists of grazed pasture dominated by herbaceous annuals, which die-out by the end of spring (e.g. Tuberaria guttata (L.) Fourr.), some drought deciduous graminea and a few shrubs (Cistus sp.). The grassland of Tojal is located at the same altitude and has the same climate as Mitra. It has a plant cover consisting of $\mathrm{C} 3$ annuals (grasses, legumes and forbs) with one invasive $\mathrm{C} 4$ grass $\mathrm{Cyn}$ odon dactylon (L.) Pers (L. Aires, private communication, 2007).The Espirra station is in a 300 ha Eucalyptus globulus plantation tended as a coppice. Originally planted in 1986 at $3 \mathrm{~m} \times 3 \mathrm{~m}$ spacing, ca. 1100 trees ha ${ }^{-1}$, was harvested at the end of the second coppice rotation (end of 2006).

Some of the plant canopy characteristics at the sites are shown in Table 1. They ranged from a tall evergreen canopy with negligible undergrowth - the eucalyptus plantation - to the low, seasonal, canopy of herbaceous plants of the grassland, or the more complex structure of the savannah-like evergreen oak woodland. The latter has a two-layer plant cover with scattered trees with ca. $21 \%$ of tree canopy cover (Carreiras et al., 2006). The estimated tree cover contribution for total leaf area index (LAI) was ca. 0.55 in average (Jarvis et al., 2007). The LAI varied intra-annually, reaching their maxima in the spring of normal rainfall years and the yearly minima in autumn. There was also an inter-annual variation. The length of the growing season varied among the vegetation types. The grassland was highly seasonal as was the 
Table 1. Characterization of the ecosystems studied and flux measuring conditions.

\begin{tabular}{|c|c|c|c|c|c|c|c|}
\hline Site & $\begin{array}{l}\text { Vegetation, main } \\
\text { plant genus }\end{array}$ & LAI & $\begin{array}{l}\text { Vegetation } \\
\text { height }\end{array}$ & Soil type & Main equipment & Tower height & $\begin{array}{l}\text { Footprint } \\
\frac{z}{L}=0.2\end{array}$ \\
\hline $\begin{array}{l}\text { Mitra } \\
38^{\circ} 32^{\prime} \mathrm{N} \\
8^{\circ} 00^{\prime} \mathrm{W} \\
256 \text { m a.s.l. }\end{array}$ & $\begin{array}{l}\text { Evergreen oak wood- } \\
\text { land: Quercus ilex } \\
\text { ssp. rotundifolia and } \\
Q . \text { suber, with un- } \\
\text { derstorey of a diver- } \\
\text { sity of C3 grasses and } \\
\text { legumes }\end{array}$ & $\begin{array}{l}\text { Maxima of } 2.3 \text { in } \\
\text { April-May and min- } \\
\text { ima ca. } 0.7(2005)\end{array}$ & $7.3 \pm 1.3 \mathrm{~m}$ & Dystric Cambisol & $\begin{array}{l}\text { R3 Gill ultrasonic } \\
\text { anemometer LI-7000 } \\
\text { (Licor) closed-path } \\
\text { IRGA }\end{array}$ & $\begin{array}{l}29 \mathrm{~m} \text {, (height of } \\
\text { sonic anemome- } \\
\text { ter) }\end{array}$ & $<800 \mathrm{~m}$ \\
\hline $\begin{array}{l}\text { Tojal } \\
38^{\circ} 28^{\prime} \mathrm{N} \\
8^{\circ} 01^{\prime} \mathrm{W} \\
190 \mathrm{~m} \text { a.s.l. }\end{array}$ & $\begin{array}{l}\text { Grassland: diversity } \\
\text { of C } 3 \text { grasses and } \\
\text { legumes + C4 invasive } \\
\text { species }\end{array}$ & $\begin{array}{l}0.4 \text { and } 2.5 \text { in } 2005 \\
\text { and } 2006\end{array}$ & $\begin{array}{l}0.4-0.5 \mathrm{~m} \\
\text { at peak } \\
\text { growth }\end{array}$ & Luvisol & $\begin{array}{l}\text { R3 Gill ultrasonic } \\
\text { anemometer LI-7500 } \\
\text { (Licor) open path IRGA }\end{array}$ & $2.5 \mathrm{~m}$ & $<300 \mathrm{~m}$ \\
\hline $\begin{array}{l}\text { Espirra } \\
38^{\circ} 38^{\prime} \mathrm{N} \\
8^{\circ} 36^{\prime} \mathrm{W} \\
95 \mathrm{~m} \text { a.s.l. }\end{array}$ & $\begin{array}{l}\text { Eucalyptus globulus } \\
\text { plantation }\end{array}$ & $\begin{array}{l}\text { Maxima of } 4.5 \text { in } \\
\text { spring of normal rain- } \\
\text { fall years and less than } \\
3 \text { in } 2005\end{array}$ & $19.9 \pm 3.0 \mathrm{~m}$ & Dystric Cambisol & $\begin{array}{l}\text { R2 Gill ultrasonic } \\
\text { anemometer LI-7500 } \\
\text { (Licor) open path IRGA }\end{array}$ & $33 \mathrm{~m}$ & $<400 \mathrm{~m}$ \\
\hline
\end{tabular}

oak woodland undergrowth. Both begin growth after the autumn rains and last until May-June when normally soil water content decreases strongly. At the other extreme was the year long evergreen eucalyptus canopy. To facilitate comparisons between the ecosystems we calculated leaf area duration (LAD) as the integral of leaf area index (LAI) along the year on a yearly basis $\left(\mathrm{m}^{2}\right.$ year $\left.\mathrm{m}^{-2}\right)$.

The three systems differed in the intensity and type of land management. In 2006 the coppiced eucalyptus plantation reached the end of the 12-year rotation, and timber was harvested by the end of the year. The estimated biomass (above ground) was $6.15 \mathrm{~kg} \mathrm{C} \mathrm{m}^{-2}$, of which $4.85 \mathrm{~kg} \mathrm{C} \mathrm{m}^{-2}$ were in round wood for the pulp mill (Sofia Cerasoli, private communication, 2007). The oak woodland is in a 300 ha estate adjacent to the Herdade da Mitra, owned by the University of Évora. The undergrowth is grazed by $0.2 \mathrm{cow} \mathrm{ha}^{-1}$ on average. The grassland was grazed every year during autumn and early winter (only during autumn in 2005), one or two times per week with a stocking density of 60 sheep ha ${ }^{-1}$. The grass is normally harvested once per year. In 2005 the drought led to a very low biomass production and, thereby, there was no harvest. In 2006, the harvest occurred in the 24 May and amounted to ca. $3.7 \mathrm{t}$ dry matter ha ${ }^{-1}$ (L. Aires, private communication, 2007).

\subsection{Field measurements}

Standard Meteorological data on rainfall, solar radiation, net radiation, wind speed and direction, humidity, temperature were collected continuously since the beginning of the project and were available in $30 \mathrm{~min}$ time steps for all localities: Évora (Mitra and Tojal) and Pegões (Espirra). Soil water volumetric content was measured in the grassland and the eucalyptus plantation, within the tower footprints, up to $30 \mathrm{~cm}$ depth using frequency domain reflectometer probes (ML2x, Delta-T Devices, Burwell, Cambridge, UK). In the oak woodland soil water content up to $15 \mathrm{~cm}$ was mea- sured using the gravimetric method - see Kurz-Besson et al. (2006). Results are presented relative to field capacity (relative water content, RWC) for the $0-20 \mathrm{~cm}$ depth soil layer, allowing a direct comparison irrespective of soil type. Whereas herbaceous communities absorb water mainly from the upper $20-30 \mathrm{~cm}$ of soils, deep rooted trees take up water from deeper soil horizons and subsoil (Kurz-Besson et al. 2006).

Surface fluxes of $\mathrm{CO}_{2}$, water vapour and energy were measured by eddy covariance. The basic equipment for these measurements was installed in each site at the top of metallic towers (Table 1). In the eucalyptus stand and in the grassland, open path gas analysers were used; these were placed according to Kirstensen et al. (1997), in order to minimise flux loss due to its separation from the sonic anemometers. The $\mathrm{CO}_{2}$ flux was measured continuously at $20 \mathrm{~Hz}$ sampling rate by the eddy covariance systems (Table 1). Soil heat flux $(G)$ was measured in the oak woodland and grassland sites.

A combined footprint and quality assessment analysis, described in Göckede et al. (2004) was performed for each site under different stability conditions. It showed the suitability of the eddy-covariance method, with the footprint isolines well within the intended surface cover type and the overall data quality being very high. The value $\frac{z}{L}=0.2$ in Table 1 gives a conservative view of the footprints as a high positive value of the stability parameter is related to reduced vertical mixing of the atmospheric boundary layer and large footprint areas. Net ecosystem exchange rate (NEE) was directly calculated as the sum of the covariant net flux of $\mathrm{CO}_{2}$ between atmosphere and ecosystem in the eddy-covariance tower footprint and the storage term. A negative value of NEE means a net carbon gain by the ecosystem, i.e., a positive net ecosystem productivity (NEP), as it may be assumed NEP to equal -NEE.

In the oak woodland, continuous measurements of tree transpiration were also done using sap flow sensors (Granier 
method) with $2 \mathrm{~cm}$ long probes, since the beginning of the project, in 4 trees of Quercus ilex ssp. rotundifolia and $3 Q$. suber trees - see David et al. (2004) and David et al. (2007) for details. This technique allowed us to separate tree transpiration from the whole ecosystem evapotranspiration (ET). The data are presented on a land area basis, which was calculated expanding from tree crown projection to ground area, taking into account the crown cover fraction within the tower footprint.

\subsection{Flux data processing and computation}

The raw data from the eddy-covariance measurements were processed off-line using the software Eddyflux (Meteotools, Jena, Germany). Given the different specifications of each site, in terms of type of cover and equipment used, the processing and post-processing (see section 2.4) of data was standardized as much as possible. The $\mathrm{CO}_{2}$ fluxes were determined, on a half-hourly basis (block averaging), by the eddy covariance method as the mean covariance between fluctuations in vertical wind speed and the carbon dioxide concentration (Baldocchi, 2003). Following the Carboeurope-IP recommendations a planar fit coordinate rotation (Wilczak et al., 2001) for wind components was performed for the forest sites (Espirra and Mitra), calculating the angle for the rotation of the vertical wind component in an annual basis, and without separation for different wind sectors, since there was no empirical evidence of improvement in the quality of the data (lower deviations to zero from the vertical wind component in an half hourly basis) when considering shorter periods or dividing in wind sectors. For the grassland site a natural wind 2-D coordinate rotation (McMillen, 1988) was performed for every averaging period, also following the Carboeurope-IP recommendations for this issue. A time lag for each averaging period was determined in order to maximise the covariance between vertical wind velocity and carbon dioxide signal from the gas analyser. The calculations also included spike detection and removal, similar to Vickers and Mahrt (1997), checking for instantaneous records exceeding realistic absolute limits and Schotanus/Liu correction (Schotanus et al., 1983; Liu and Peters, 2001) for sonic temperature and sensible heat flux. In addition, the air density fluctuations were taken into account to correct the fluxes of carbon dioxide (Webb et al., 1980) of the grassland and eucalyptus sites. The fluxes of the oak woodland were corrected for the damping loss of the closed-path analyser at high frequencies, according to Eugster and Senn (1995). In general, the correction factors varied between 1.05 and 1.30. $\mathrm{A} \mathrm{CO}_{2}$ storage term, calculated for one point measurement as in Greco and Baldocchi (1996), was added to the estimated carbon flux for both, eucalyptus and oak woodland data. In the grassland this storage term was negligible.

\subsection{Data quality control, gap-filling and flux partitioning}

The quality of all primary data was guaranteed by a routine of equipment calibration and, for meteorological data, a comparison with data from nearby stations. To exclude non-representative 30-min measurements of carbon dioxide flux, the following screening criteria were applied: fluxes were removed if the mean vertical velocity deviation to zero was higher than what would be considered as normal for each site, following the same principle as in Rebmann et al. (2005); fluxes were excluded if the high frequency spikes replaced or the absolute limits violations exceeded $1 \%$ of the total records of any of the three components of wind velocity and/or $\mathrm{CO}_{2}$ concentration.

Here we followed the 3 flags scheme (Mauder and Foken, 2004): 0,1 and 2, in which 0 represents data of highest quality, to use in fundamental research, 1 data for use in long term observation programs and 2 data that should not be considered and, hence, substituted by gap filling. Data rejected after the filtering process was flagged 2 . The remaining data were subsequently submitted to integral turbulence characteristics (of the vertical wind) and stationarity tests, and flagged as 0,1 or 2 according to the results $(0: 0-30 \%$ deviation; 1 : $30-50 \%$ deviation; 2 : $>50 \%$ deviation).

The use of such tests tend to reduce significantly the role of the $u_{*}$ filtering (see Wohlfahrt et al., 2005) by eliminating most of the fluxes that are usually removed by it. However, we followed a conservative approach in which fluxes were also excluded if the friction velocity $\left(u_{*}\right)$ was below the threshold of $0.2 \mathrm{~m} \mathrm{~s}^{-1}$, for the Espirra and Mitra sites, and $0.08 \mathrm{~m} \mathrm{~s}^{-1}$, for the grassland site. The $u_{*}$ threshold was determined graphically by plotting the night-time NEE as a function of $u_{*}$ (e.g. Anthoni et al., 2004).

Total data gaps during the whole study period, due to missing and rejected data, were about $56 \%, 57 \%$ and $42 \%$ for the eucalyptus, oak woodland and grassland, respectively. Gap filling and flux-partitioning methods proposed by Reichstein et al. (2005) were used to fill data gaps and to separate the net ecosystem exchange (NEE) into gross primary production (GPP) and ecosystem respiration (Reco), respectively.

As an overall quality indicator we analysed the closure error for the energy balance equation, using daily values, (after gap filling) and considering the whole study period, for the grassland and eucalyptus sites and only 2006 for the oak woodland. The closure errors were 12 and $17 \%$ for the grassland and eucalyptus sites, respectively. For the oak woodland, closure error was $32 \%$, but only the year of 2006 was analysed due to soil heat flux measurements availability. The high closure error of the oak woodland site may have been partly a result of the inherent difficulty in obtaining representative measurements of $R n$ and $G$, in such heterogeneous landscape. 
Table 2. Precipitation in Évora - Mitra in each of the hydrologicalyears (i.e., the period between 1 October and 30 September of the following year) of the experiment.

\begin{tabular}{cc}
\hline Hydrological-year & Precipitation, $\mathrm{mm}$ \\
\hline $2001 / 2002$ & 650.2 \\
$2002 / 2003$ & 696.4 \\
$2003 / 2004$ & 560.0 \\
$2004 / 2005$ & 345.2 \\
$2005 / 2006$ & 685.4 \\
\hline
\end{tabular}

\subsection{Data analysis}

We calculated the NEE, GPP and Reco from 2003 through 2006, except for the grassland, which was installed later and had data only after the autumn of 2004. Data were analyzed at different time scales: seasonally, as well as in terms of hydrological-years. Seasonal data are presented as monthly averages or 3-months sums (rainfall), with e.g., winter corresponding to January + February + March. To compare the use of resources for primary production by the ecosystems we calculated gross ecological light use efficiency, LUE $\mathrm{ecol}_{\text {, }}$ ( $\mathrm{mmol} \mathrm{mol}^{-1}$ ) according to Gilmanov et al. (2007) as the fraction between daily GPP and daily incident photosynthetic photon flux density, and Rain-use-efficiency as RUE $=$ GPP/precipitation $\left(\mathrm{g} \mathrm{C} \mathrm{L}^{-1}\right.$ (Lauenroth et al., 2000; Huxman et al., 2004). Monthly averages were used to compare the time variation and inter-site differences. These parameters were chosen because they are simple and either related to the major limiting factor in Mediterranean climates, e.g. RUE, or related to GPP determinants such as leaf area duration (LAD). The LAD was calculated as the integral of leaf area index (LAI) allong the year and can be considered as a surrugate for the annual photosynthetic photon flux density absorbed by the plant canopy (APAR).

\section{Results and discussion}

\subsection{Conditions during the experiment}

The meteorological conditions were monitored from January 2002 to December 2006 in Évora - Mitra and Espirra. They followed the same patterns in both locations. Since ÉvoraMitra had a longer data set, we reported the data for this location, unless stated otherwise. During the hydrologicalyears of the experiment $(2001 / 2002$ to $2005 / 2006)$ the mean air temperature varied between $15.8^{\circ} \mathrm{C}$ and $16.1^{\circ} \mathrm{C}$ and solar radiation varied between $6473 \mathrm{MJ} \mathrm{m}^{-2}$ in $2004-2005$ and $6085 \mathrm{MJ} \mathrm{m}^{-2}$ in $2002-2003$. The rainfall totals are shown in Table 2. Figure 1 shows the anomaly of mean seasonal rainfall in relation to the long-term average (1961-1990) throughout the experiment. Roughly, 2002-2003 was about

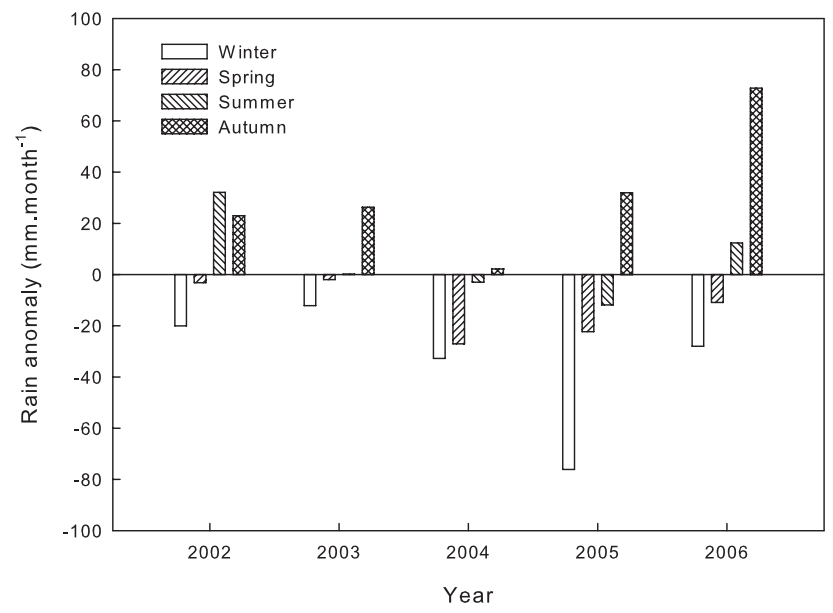

Fig. 1. Deviation of mean seasonal rainfall from the long-term average (1961-1990) in Mitra (Évora). Portugal.

"normal", 2003-2004 and 2004-2005 were two consecutive dry years, with annual rainfall amounting to 84 and $52 \%$ of the long-term local average, respectively. The hydrologicalyear of 2004-2005 was an outstanding dry spell in southwest Europe with low annual precipitation and a unusual seasonal rain pattern because winter rainfall was extremely low (only $10 \%$ of the long-term mean). The hydrological-year of 20052006 was about normal, i.e., rainfall equal to the long-term mean (Fig. 1) confirmed the tendency for wetter autumns in the western Iberian Peninsula. The dry years followed the tendency for a strong negative rain anomaly in winter-spring (Paredes et al., 2006).

3.2 Inter-annual variation and differences between vegetation types

Figure 2 shows the variation in NEE, GPP and Reco for the 3 sites in the hydrological-years 2002/2003 to 2005/2006. The eucalyptus plantation was always the strongest sink for carbon $\left(-861\right.$ to $-399 \mathrm{~g} \mathrm{C} \mathrm{m}^{-2}$ year $\left.^{-1}\right)$ whereas the oak woodland and the grassland were much weaker sinks for carbon: NEE varied between -140 and $-28 \mathrm{gC} \mathrm{m}^{-2}$ year $^{-1}$ in the oak woodland and between -190 and $+49 \mathrm{~g} \mathrm{C} \mathrm{m}^{-2}$ year $^{-1}$ in the grassland. The highest value of carbon sequestration by the eucalyptus plantation (negative NEE) occurred in the wetter hydrologicalyear of 2002-2003, with $\mathrm{NEE}=-861 \mathrm{gCm}^{-2}$ year $^{-1}$. The oak woodland was a much weaker sink for carbon with a NEE of $-38 \mathrm{gCm}^{-2}$ year $^{-1}$ in 2003- 2004 but reaching $-140 \mathrm{gCm}^{-2}$ year $^{-1}$ in 2005-2006. Likewise, the grassland had a NEE of $-190 \mathrm{gCm}^{-2}$ year $^{-1}$ in 2005-2006. In all cases, NEE was less negative (or even positive in the case of the grassland) during the dry hydrological-year of 2004-2005. In that year, the strongest sink for carbon was the eucalyptus plantation $\left(\mathrm{NEE}=-399 \mathrm{~g} \mathrm{C} \mathrm{m}^{-2}\right.$ year $\left.^{-1}\right)$. The hydrological-year of 2005-2006 had a normal rainfall (see 


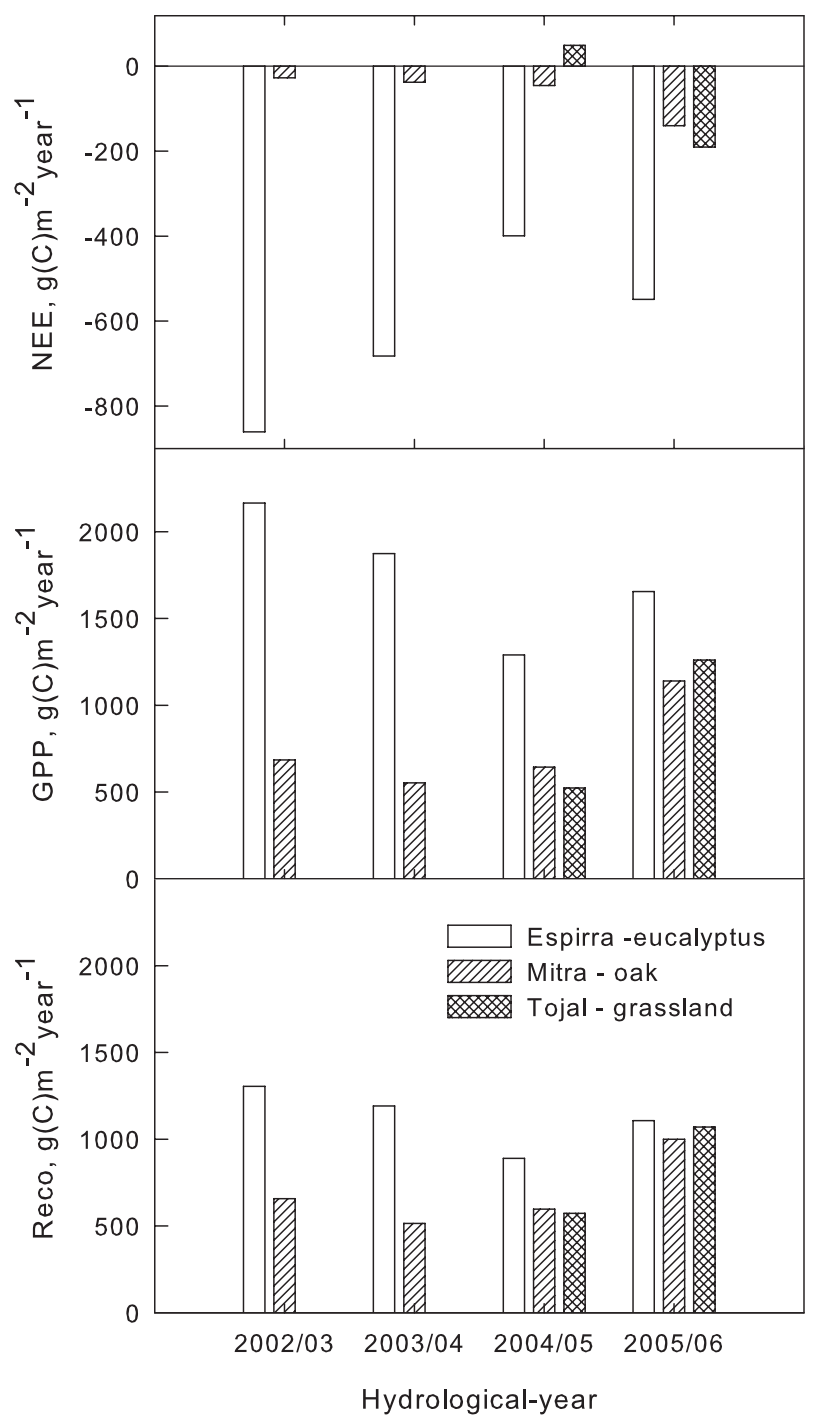

Fig. 2. Hydrological-year totals of net ecosystem exchange (NEE), gross primary production (GPP) and ecosystem respiration (Reco) during the experiment for the three sites (Espirra - eucalyptus plantation; Mitra - oak woodland and Tojal - grassland). See text for definition of hydrological-year.

Table 2) and although the net ecosystem productivity of the grassland and oak woodland reached their maxima, the eucalyptus plantation did not fully recover to the values prior to the 2004-2005 drought.

The values for ecosystem carbon balance compare well with flux measures of carbon sequestration in similar ecosystems. For example, the NEE of the eucalyptus plantation was similar to that of a Pinus pinaster stand in Bordeaux, France $-570 \mathrm{gCm}^{-2}$ year $^{-1}$ (Berbigier et al., 2001) and a short-rotation coppice of poplar in Belgium, $-620 \mathrm{gCm}^{-2}$ year $^{-1}$ (Deckmyn et al., 2004). However, the variability across environments, between species and with stand characteristics, may be very large. The estimated co- efficient of variation was $62 \%$ for a sample of European forests where eddy covariance carbon fluxes have been measured (Janssens et al., 2003). The variability was large also for a group of European grasslands in the CarboEurope network: an average NEE of $-150 \mathrm{gCm}^{-2}$ year $^{-1}$, with a maximum of $-654 \mathrm{gCm}^{-2}$ year $^{-1}$ and minima up to $+163.6 \mathrm{gCm}^{-2}$ year $^{-1}$, in the arid part of the climatic gradient studied (Gilmanov et al., 2007). The values measured in the Tojal grassland fell well within this range in both years studied. In a Mediterranean grassland in California, NEE was $-132 \mathrm{gCm}^{-2}$ year $^{-1}$, in one year and changed to a carbon source $\left(+29 \mathrm{gCm}^{-2}\right.$ year $\left.^{-1}\right)$ in the following year (Xu and Baldocchi, 2004). Although compatible with the estimated average for European forests, $-124 \mathrm{gCm}^{-2}$ year $^{-1}$ (Janssens et al., 2003), the NEE of the oak woodland in Mitra can be compared to other oak savannahs. For example, the Portuguese stand was less productive than a deciduous-oak savannah under a Mediterranean climate in California, which reached $-260 \mathrm{gCm}^{-2}$ year $^{-1}$ (Baldocchi and Xu 2004). In fact NEE was also lower than in a closed canopy mature Quercus cerris forest in central Italy: $\mathrm{NEE}=-381 \mathrm{gCm}^{-2}$ year $^{-1}$ (Kowalski et al., 2004), possibly due to the low population density of mature trees $\left(35\right.$ trees ha $\left.^{-1}\right)$ in our woodland.

Annual GPP increases linearly with increasing absorbed photosynthetically active radiation (APAR) (Russell et al., 1989). As climate is similar in the three sites, the differences between them can be ascribed to plant characteristics that affect either different slopes of the relation between GPP and APAR, (light use efficiency at leaf level) or in APAR itself.

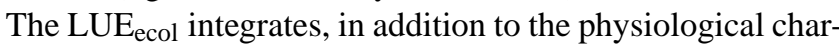
acteristics, the efficiency of light capture itself. The LUE $\mathrm{E}_{\text {ecol }}$ values shown in Fig. 3 are in agreement with those reported for a variety of ecosystems (Gilmanov et al., 2005). The eucalyptus plantation canopy was almost twice as efficient (on average) as the oak woodland in normally wet years, but it decreased substantially during the dry year. Drought inhibition of photosynthesis may explain most of the difference between years.

But differences in APAR also played a role in plant response in different years. As incident solar radiation was nearly the same in the three sites, differences in APAR were related to changes in leaf area index (LAI) and the length of the growing season, or leaf area duration (LAD) (Palmroth et al., 2006). In all cases the minimum estimated LAD occurred in 2004-2005. In the grassland it was $0.3 \mathrm{~m}^{2} \times$ year $\mathrm{m}^{-2}$ in 2004-2005 and increased to $0.74 \mathrm{~m}^{2} \times$ year m ${ }^{-2}$ in 20052006, whereas in the oak woodland was $0.75 \mathrm{~m}^{2} \times$ year m $\mathrm{m}^{-2}$ in 2004-2005 and nearly 1 to $1.3 \mathrm{~m}^{2} \times$ year m ${ }^{-2}$ otherwise. The LAD of the eucalyptus plantation was highest, ranging from $2.9 \mathrm{~m}^{2} \times$ year $\mathrm{m}^{-2}$ in the wet hydrological-years to $2.3 \mathrm{~m}^{2} \times$ year m $\mathrm{m}^{-2}$ in the dry 2004-2005. In spite of differences in photosynthetic capacity, there was a linear relationship between GPP and LAD for the three ecosystems (Fig. 4), thus suggesting that APAR was indeed a major factor in dif- 


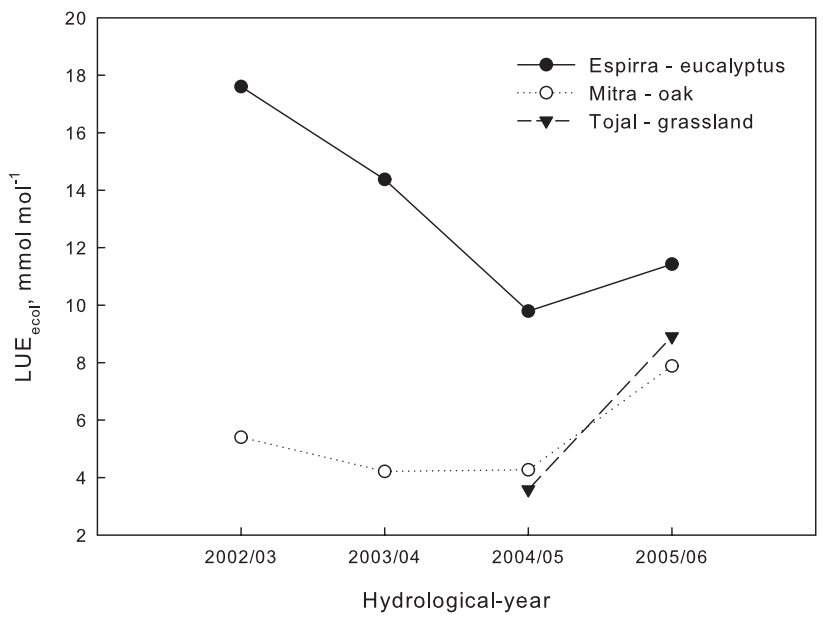

Fig. 3. Gross ecological light use efficiency $\left(\mathrm{LUE}_{\mathrm{ecol}} \mathrm{mmol} \mathrm{mol}^{-1}\right)$ expressed in monthly averages for the three experimental sites: Espirra - eucalyptus plantation; Mitra - oak savannah and Tojal grassland.

ferentiating between vegetation types. For example, the evergreen nature of the eucalyptus canopy and high tree density allowed a high LAI to be maintained over the whole year and, therefore, elevated GPP.

Assuming that the LAD of the oak trees was $0.55 \mathrm{~m}^{2} \times$ year $\mathrm{m}^{-2}$, the value of the LAD for the grassland and for the oak woodland undergrowth in 2005, were similar. In the oak woodland, the grass cover may account for up to $70 \%$ of the maximum LAI in spring, but is reduced to near zero in summer. The sparse oak tree cover, however, continued to photosynthesize throughout the summer. A similar situation happened in grassland in summer but as a result of the activity of a sole $\mathrm{C} 4$ grass, $C$. dactylon, which maintained some photosynthesis in summer. Its contribution for the seasonal carbon balance was, nevertheless, not enough to compensate for the larger Reco (L. Aires, private communication, 2007).

\subsection{Seasonal variation}

There was a marked seasonality in the pattern of net carbon assimilation by the ecosystems studied (Fig. 5). As expected, (e.g., Baldocchi and Xu 2004) the maximum productivity (GPP) and NEE occurred in spring. In summer, water deficits caused stomatal closure (trees) and leaf senescence (herbs) and therefore a generalized decrease in GPP. Upon soil rewetting in autumn there is a vegetation recovery towards winter. The seasonal patterns were very similar in the three ecosystems. For example, the monthly NEE totals of the oak woodland and the grassland were similar: the $r^{2}$ of the linear regression between monthly averages of NEE from the oak woodland and the grassland in 2005 and 2006, forced as a 1:1 line, was 0.68. This degree of similitude was remarkable, considering that, although the sites are near each other, the measurement methods used in each site

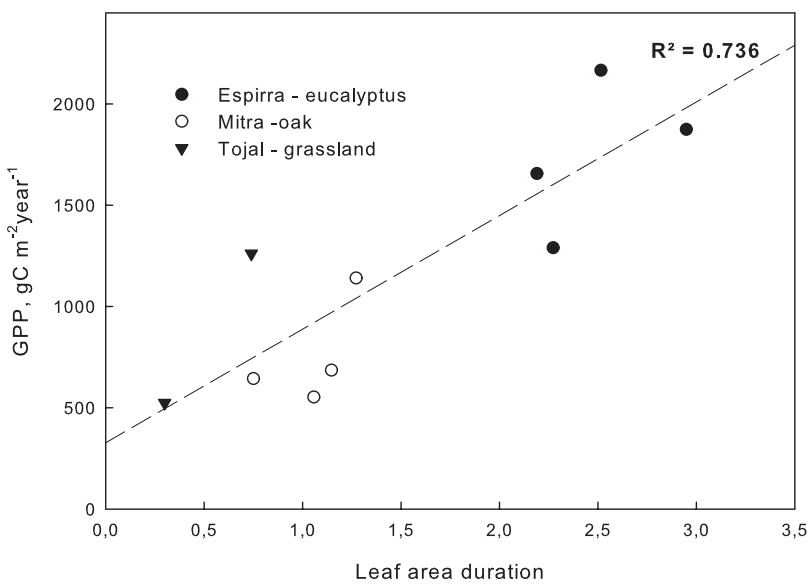

Fig. 4. Relationship between GPP and leaf area duration (LAD) in the three experimental sites: Espirra - eucalyptus plantation; Mitra - oak woodland; and Tojal - grassland) for the extent of the study (the grassland was studied only in the hydrological years 2004-2005 and 2005-2006). The linear regression line is plotted: $R=0.858, R^{2}=0.736$ (indicated near the regression line); regression $P<0.002$.

were quite different (Table 1) and the tower footprint much larger in the oak woodland. This suggests (1) the similarity of seasonal patterns of carbon metabolism in the two systems and (2) that the density of mature trees in the oak woodland was not high enough to overcome the role of the herbaceous community on ecosystem functioning. The comparison between the oak woodland and the eucalyptus plantation also yielded a reasonable linear correlation $\left(r^{2}=0.72\right)$, although the monthly averages of NEE were very different. This suggests some homogeneity in the seasonal pattern of ecosystem carbon metabolism throughout the region.

The monthly variation $\mathrm{LUE}_{\text {ecol }}$ (in $\mathrm{mmol} \mathrm{mol}^{-1}$ ) indicated a maximum in winter: $8.64 \pm 1.74$ and $17.09 \pm 2.73$, in the oak and eucalyptus stands, respectively. These values were 57\% and $29 \%$ above their respective yearly averages. This can be explained by abundant water and lower light intensity with a greater proportion of diffuse light in winter as compared to spring and summer. In Évora the amount of diffuse light was 38\%-39\% in winter and autumn and $27 \%$ in summer (in spring, 34\%). Diffuse light is more efficient for photosynthesis than direct light and may increase LUE (Rosati and Dejong, 2003). In summer, the $\mathrm{LUE}_{\text {ecol }}$ decreased to values near $\frac{1}{2}$ of the yearly average and the oak woodland, as well as the grassland, became sources of carbon, as Reco exceeded GPP (Fig. 5). In autumn, the $\mathrm{LUE}_{\mathrm{ecol}}$ was quite variable. It was lower in the systems that had an important herbaceous component (grassland and oak woodland) than in the eucalyptus stand. In the latter the $\mathrm{LUE}_{\text {ecol }}$ of autumn and winter were similar, whereas the autumn LUE ecol was lower as compared to the winter in grassland and oak woodland. The reasons for this low $L_{U E}$ ecol in autumn may be the consequence of a low leaf area displayed and low photosynthetic activity as 


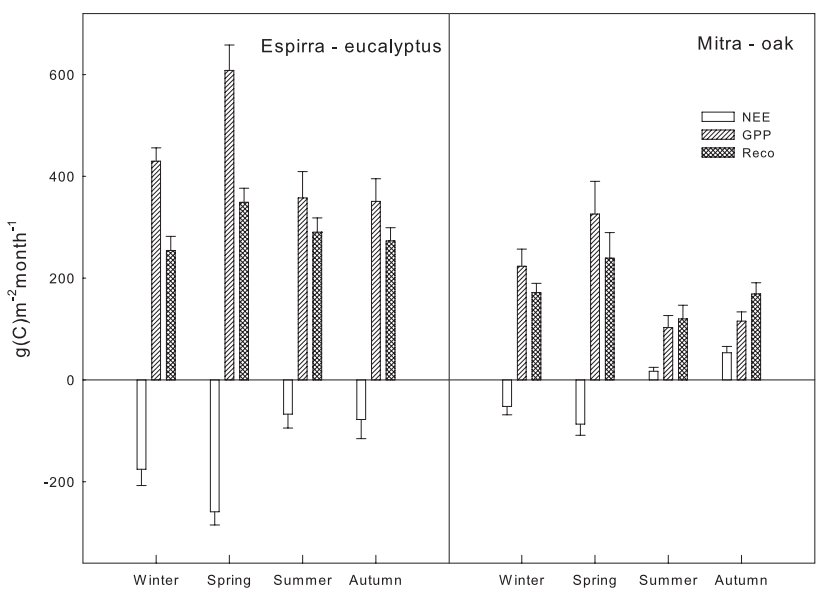

Fig. 5. Average seasonal variation of NEE, GPP and Reco for the eucalyptus plantation and the oak savannah (Espirra and Mitra sites, respectively) during the experimental period (4 year averages with standard error).

compared to tissue respiration in the developing canopy of the grassland, and the oak woodland understorey.

Ecosystem respiration is a very important component of carbon balance showing a clear seasonality with lower rates during drought periods and in winter (Reichstein et al., 2002). In our work the eucalyptus stand and the grass dominated systems differed: whereas in the latter the minimum Reco occurred in summer, as a result of drought and the death of herbaceous plants, in the eucalyptus stand, summer respiration was above the winter rates (Fig. 5). One may speculate that in the summer, the eucalyptus stand had an abundance of live roots in the soil and current canopy photosynthesis while the autotrophic component of Reco in the grassland and woodland must be very low (Tang and Baldocchi, 2005). In systems with an important herbaceous component this situation extends through autumn. The rains at the end of the dry season will fall before the grassland canopy grows. In the autumn of 2005, for example, after abundant rainfall (see Fig. 1), the woodland Reco was very high and almost $50 \%$ above GPP. The rewetting of the dry soil with the rains at the end of the dry season promoted large $\mathrm{CO}_{2}$ effluxes (Jarvis et al., 2007) and a yet unknown contribution to ecosystem carbon balance.

\subsection{The effect of drought}

In Mediterranean type of environments the summer drought marks the seasonality. But periods with a shortage of precipitation that may negatively affect the normal functioning of ecosystems occur with increasing frequency (Miranda et al., 2006). The seasonal depression in net carbon assimilation due to summer water deficits occur as (1) photosynthetic rates of perennials become limited by the combination of seasonal water deficits, high light and elevated temperatures (Chaves et al., 2002), (2) shallow-rooted herbs and shrubs

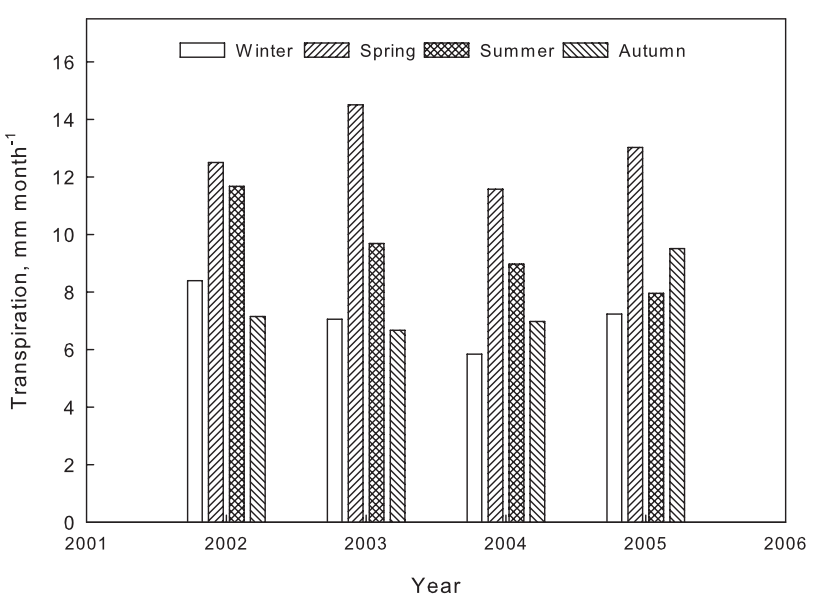

Fig. 6. Seasonal variation in tree transpiration (sap flow) on a ground area basis. assuming a $21 \%$ tree crown cover (monthly averages) during part of the experimental period (2002-2005) in the oak woodland.

senesce and die and (3) ecosystem respiration is less inhibited than primary production by summer conditions (Tang and Baldocchi 2005). In this study the oak woodland had a more pronounced depression in carbon balance in summerautum than the eucalyptus plantation, as the woodland Reco was systematically greater than GPP in that period (Fig. 5). We may hypothesise that the grassland would behave similarly to the oak woodland, except with a lower Reco, as the presence of metabolically active trees (see below) might increase this component, both as a result of live biomass respiration and soil (tree root) respiration (Tang and Baldocchi, 2005).

With little rain and high evaporative demand at the transition between the wet and dry seasons (mid-May onwards) soil water is exhausted up to the grass/shrub rooting depth $(20-30 \mathrm{~cm})$ and GPP diminishes drastically. In years with normal winter rainfall, e.g., 2004 and 2006, the amount of extractable water or relative soil water content (RWC) of the top soil layer $(0-20 \mathrm{~cm})$ decreased from field capacity in winter to 0.2 in the oak and grassland sites and 0.1 in the eucalyptus site at the end of the summer. The herbaceous plants of the oak woodland, as T. guttata, reached very low predawn leaf water potentials $(-1.5 \mathrm{MPa})$, reflecting the upper soil water depletion (S. Unger, private communication, 2007) when the soil RWC reached 0.30 or 0.40 . Meanwhile, the oak trees maintained a reasonable rate of transpiration (Fig. 6) and a fairly high predawn leaf water potentials $(-0.5 \mathrm{MPa})$, indicating access to sufficient water supply, In a nearby location in Mitra, the soil RWC at $1 \mathrm{~m}$ depth remained near field capacity until late June (Kurz-Besson et al., 2006), suggesting the absence of root water absorption until the end of spring. After the senescence of the herbaceous layer, trees maintained a considerable transpiration throughout the summer as described by David et al. (2007) for the Mitra oak woodland in 2001-2003 (see also Fig. 6). Even though tree wa- 
ter status deteriorate (predawn leaf water potential decreased substantially), by the end of the summer, more than $70 \%$ of the transpired water was taken from groundwater sources.

The lack of precipitation in 2004-2005 was a climatic anomaly distinct from the regular occurrence of seasonal low precipitation that created a temporary drought that negatively interfered with canopy development, GPP and net ecosystem productivity (NEP). The $\mathrm{LUE}_{\mathrm{ecol}}$ of the dry hydrologicalyear (2004-2005) was 31\% below the average for the other years in the eucalyptus stand and the oak woodland. In the grassland the GPP was drastically affected and LUE $E_{\text {ecol }}$ was $60 \%$ below the normal hydrological-year of 2005-2006. As respiration was less affected than carbon assimilation, the grassland Reco exceeded GPP by $55 \%$ in the dry summer (2005) but only by $10 \%$ in the summer of 2006 . The differences were less marked in the other ecosystems, but the eucalyptus plantation became temporarily (summer) and for the first time during this study, a source of carbon (Fig. 2).

The impact of drought can be evaluated not only by its direct effects - decreases in GPP and NEE, for example but also by the recovery after drought alleviation. In this study the eucalyptus stand was apparently less sensitive to drought than the oak woodland, acting as a carbon sink throughout the observation period. It could even withstand the rainfall shortage of 2003-2004 (precipitation 84\% of the long term average) without a great change in NEE. As mentioned above, the recovery after drought was however less pronounced than in the other systems as GPP and LUE ecol were in 2005-2006 below the values before the drought. This delay had a structural basis as the eucalyptus stand had the lowest LAD value in 2005-2006, an indication that the plantation did not fully recover in the hydrological-year after the extreme drought. The contrary occurred in the oak woodland as GPP fully recovered from drought after 2004-2005, reaching $-140 \mathrm{gCm}^{-2}$ year $^{-1}$ in $2005-2006$. The causes for the low recovery in the eucalyptus, however, might be fortuitous - e.g., exceptionally good condition for the herbaceous communities in 2005-2006, rather than a sluggish response of eucalyptus to drought alleviation. The eucalyptus stand might be already in the declining productivity phase, as it approached the end of the second rotation.

A situation of dehydration avoidance was clearly observed in the eucalypt and oak trees, which kept the stomata partly open during the dry part of the 2004-2005 hydrological-year, as discussed above. In periods of shortage of current precipitation the use of soil water reserves by the trees increased. For example, whereas tree transpiration (sap flow) in the oak woodland was ca. $18 \%$ of the rainfall in normal years, rose to $30 \%$ during the drought (hydrological-year of 2004-2005). In the eucalyptus stand the average evapotranspiration (data not shown) was equal to rainfall in years of normal precipitation, but was $44 \%$ above annual precipitation in the dry hydrological-year (2004-2005). This suggests that the effects of drought on Mediterranean sclerophyllous trees occur mainly after the depletion of the deep soil and ground water

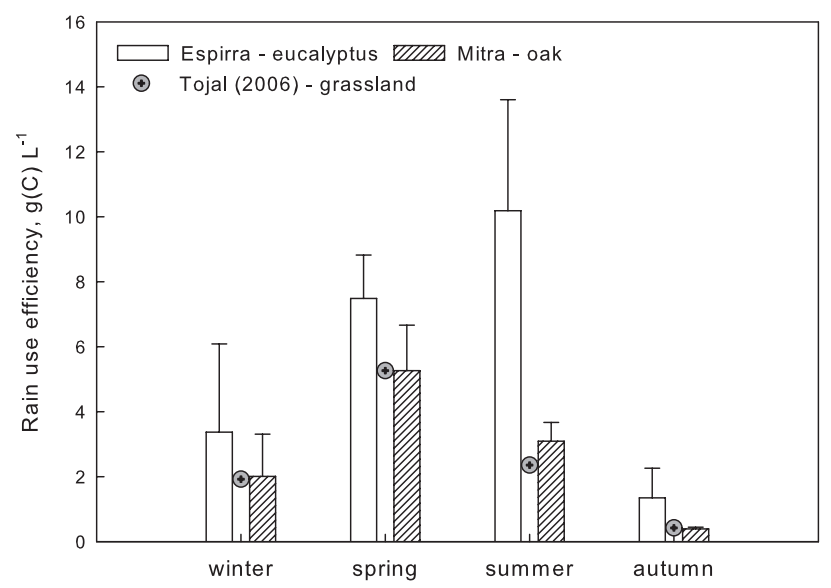

Fig. 7. Seasonal variation in GPP rain use efficiency (GPP/precipitation. $\mathrm{gCL}^{-1}$ ) in two experimental sites (Espirra eucalyptus plantation and Mitra - oak woodland) during the experimental period (4 years - 2003-2006 - averages with standard error). The 2006 value for the Tojal grassland is also shown.

reserves, as most species have deep rooting habits (Canadell et al., 1996; David et al., 2007; Schenk and Jackson, 2005; Pereira et al., 2006).

Defining vulnerability as the characteristic of an ecosystem regarding its capacity to resist and/or recover from the impacts of an adverse event, the differences in vulnerability to drought between ecosystems were related to rooting depth and canopy extension: the eucalyptus plantation could delay water stress through the use of a large volume of soil, but depended on the regularity of winter precipitation to recharge deeper soil water. The vulnerability of the eucalyptus plantation to drought is shown by the delayed recovery after the severe drought of 2004-2005 (Fig. 2). Mediterranean grasslands are most sensitive to drought as the plants are strict drought avoiders that have their life cycle tuned to the duration of soil water abundance. Whereas the herbaceous understorey dominated the response of the oak savannah, the tree population seems to allow some carbon assimilation in summer, while exerting some pressure on groundwater reserves. Given the low tree density of the specific woodland studied, one may speculate that trees may withstand longer sequences of dry years than closed canopy forests, which utilize a greater proportion of soil water reserves.

\subsection{Rain use efficiency}

One simple way of assessing the effectiveness of the utilization of local water resources is to quantify of rain-use efficiency (RUE) (Huxman et al., 2004; Lauenroth et al. 2000). It represents the amount of rainfall water required for primary production. It the depends not only on the efficiency of transpiration (physiologically productive water flow), but also on the proportion of "non-productive" water fluxes, i.e., the other terms of the water balance that occur outside the plant - runoff, canopy interception losses - that are virtually 
non-productive (Pereira et al., 2006). As it may be expected, RUE decreases as water supply increases - e.g., see the lower RUE in winter in Fig. 7 (Loustau et al., 2001; Huxman et al., 2004). In humid regions and during the Mediterranean wet seasons, this decrease results from precipitation being normally above potential evapotranspiration (PET) and therefore not all the water available being used.

Natural vegetation appears to converge (at the biome level) towards the same maximum RUE in the driest years in the region, when water is the major limiting resource (Huxman et al., 2004). In our experimental sites, however, the difference between vegetation types increased with drought. The eucalyptus plantation increased RUE in the dry year of 20042005 to $5.2 \mathrm{gC} \mathrm{L}^{-1}$ (ca. 80\% higher than the average of the wetter hydrological-years, $2.9 \mathrm{gC} \mathrm{L}^{-1}$ ), whereas the RUE of the oak woodland remained below ca. $2.0 \mathrm{gC} \mathrm{L}^{-1}$, i.e., changed less with drought (increased 54\% relative to the average of the wetter years, ca. $1.2 \mathrm{gC} \mathrm{L}^{-1}$ ).

We may speculate that the increase in RUE in the eucalyptus resulted from tree access to water stored in the soil from previous years, as roots were able to extract water from deeper soil horizons or the subsoil. In the oak woodland, although this happens to trees (David et al., 2007) it certainly did not in the herbaceous component. In fact, the RUE of the grassland in the two years of study was similar to the oak woodland. Herbaceous vegetation, with a fixed supply of water from the upper soil horizons, does not tolerate water deficits and die whenever the soil water is not replenished. This means that RUE of grasslands in a seasonally dry environment may be lower because they will waste rain at the beginning of the growth period, before the canopy develops (Lauenroth et al., 2000). For similar reasons, they do not use water from isolated rain pulses, especially if they occur at long intervals. This will negatively affect the capability to use rainfall, will reduce RUE and may be a strong limitation to carbon sequestration and nutrient cycling (Jarvis et al., 2007). In the case of woody vegetation with access to water stored in the soil from previous years, it may take longer than one year of drought to affect RUE negatively. On the other hand, if climate change scenarios hold true, or for that matter the present tendencies prevail in western Mediterranean, with longer dry seasons (Miranda et al., 2006; Paredes et al., 2006), one may expect RUE to increase little at least in annual vegetation. One may speculate that the fate of deep rooted woody vegetation will depend upon the frequency of droughts.

\section{Concluding remarks}

We compared the carbon balance of three ecosystems typical of major landscape types of southern Portugal, based on the eddy covariance direct measure of net carbon exchange between the ecosystem and the atmosphere, under the same climate. The gross primary productivity was linearly related to $\mathrm{LAD}$, a surrogate for absorbed photosynthetic photon flux density (APAR), dependent on LAI and length of the growing period The eucalyptus plantation was always the strongest sink for carbon as it had a high GPP due to a high LAD (and high photosynthetic rates) and a modest proportion (ca. 70\%) of assimilated carbon spent in respiration. In the systems dominated by non-woody vegetation - oak woodland and grassland - the NEE was in average ca. fourfold lower than in the eucalyptus. In thee oak woodland and grassland, not only GPP was lower (shorter growing season), but also the ecosystem carbon losses (Reco) corresponded to a greater proportion of GPP than in eucalyptus. Seasonally, the relative importance of ecosystem respiration increased from winter to summer and autumn, reaching values above GPP (i.e., positive NEE) in the grassland or the oak woodland. In these ecosystems the period with full plant cover was limited (October to mid-May) and the first rains after the seasonal drought tend to be wasted, flowing along "non-productive" paths, simply because the herbaceous plant canopy was not there.

The period under analysis (2003-2006) included the hydrological year of 2004-2005, when a severe drougth affected the region. It was the driest episode in the last 140 years. During the hydrological year of 2004-2005, there was a generalised decrease in gross primary production and carbon sequestration, with the grassland becoming a net source of carbon to the atmosphere. Indirect evidence confirm that trees, both eucalyptus and the scattered evergreen oaks, had the capability of exploring larger soil volumes than the shallow-rooted herbaceous, surviving the drought and assimilating some carbon using the water stored in the soil free from the competition of other plants. The closed canopy plantation seems to be less sensitive to moderate droughts, e.g., 2003-2004, but more vulnerable to severe droughts (2004-2005) than the systems dominated by herbaceous plants, as suggested by its relatively sluggish recovery after drought alleviation in 2005-2006.

Acknowledgements. The authors wish to thank A. Correia and C. Nogueira for their assistance; C. Kurz-Besson and S. Cerasoli for information on soil water measurements in Mitra and Espirra; CARBOEUROPE - IP project - Assessment of the European terrestrial carbon balance (GOCE-CT-2003-505572); FCT - Foundation for Science and Technology, Portugal for financial support through a Ph.D. grant to L. M. Aires and a Post-doc fellowship for T. Afonso do Paço.

Edited by: F. X. Meixner 


\section{References}

Anthoni, P. M., Freibauer, A., Kolle, O., and Schulze, E. D.: Winter wheat carbon exchange in Thuringia, Germany, Agric. Forest Meteorol., 121, 55-67, 2004.

Baldocchi, D. D.: Assessing the eddy covariance technique for evaluating carbon dioxide exchange rates of ecosystems: Past, present and future, Global Change Biol., 9, 479-492, 2003.

Baldocchi, D. and $\mathrm{Xu}$, L.: Carbon exchange of deciduous broadleaved forests in temperate and Mediterranean regions, in: The carbon balance of forest biomes, edited by: Griffiths, H. and Jarvis, P. G., Garland Science/BIOS Scientific Publishers, Oxford, 187-214, 2004.

Baldocchi, D. D., Xu, L. K., and Kiang, N.: How plant functionaltype, weather, seasonal drought, and soil physical properties alter water and energy fluxes of an oak-grass savanna and an annual grassland, Agric. Forest Meteorol., 123, 13-39, 2004.

Berbigier, P., Bonnefond, J. M., and Mellmann, P.: $\mathrm{CO}_{2}$ and water vapour fluxes for 2 years above euroflux forest site, Agric. Forest Meteorol., 108, 183-197, 2001.

Canadell, J., Jackson, R. B., Ehleringer, J. R., Mooney, H. A., Sala, O. E., and Schulze, E. D.: Maximum rooting depth of vegetation types at the global scale, Oecologia, 108, 583-595, 1996.

Carreiras, J. M. B., Pereira, J. M. C., and Pereira, J. S.: Estimation of tree canopy cover in evergreen oak woodlands using remote sensing, Forest Ecol. Manage., 223, 45-53, 2006.

Chaves, M. M., Pereira, J. S., Maroco, J., Rodrigues, M. L., Ricardo, C. P. P., Osório, M. L., Carvalho, I., Faria, T., and Pinheiro, C.: How plants cope with water stress in the field? Photosynthesis and growth, Ann. Botany, 89, 907-916, 2002.

Ciais, P., Reichstein, M., Viovy, N., Granier, A., Ogee, J., Allard, V., Aubinet, M., Buchmann, N., Bernhofer, C., Carrara, A., Chevallier, F., De Noblet, N., Friend, A. D., Friedlingstein, P.,Grunwald, T., Heinesch, B., Keronen, P., Knohl, A., Krinner, G., Loustau, D., Manca, G., Matteucci, G., Miglietta, F., Ourcival, J. M., Papale, D., Pilegaard, K., Rambal, S., Seufert, G., Soussana, J. F., Sanz, M. J., Schulze, E. D., Vesala, T., and Valentini, R.: Europewide reduction in primary productivity caused by the heat and drought in 2003, Nature, 437, 529-533, 2005.

David, T. S., Ferreira, M. I., Cohen, S., Pereira, J. S., and David, J. S.: Constraints on transpiration from an evergreen oak tree in southern Portugal, Agric. Forest Meteorol., 122, 193-205, 2004.

David, T. S., Henriques, M. O., Kurz-Besson, C., Nunes, J., Valente, F., Vaz, M., Pereira, J. S., Siegwolf, R., Chaves, M. M., Gazarini, L. C., and David, J. S.: Water use strategies in two co-occurring Mediterranean evergreen oaks: Surviving the summer drought, Tree Physiology, 27, 793-803, 2007.

Deckmyn, G., Muys, B., Garcia Quijano, J., and Ceulemans, R.: Carbon sequestration following afforestation of agricultural soils: Comparing oak/beech forest to short-rotation poplar coppice combining a process and a carbon accounting model, Global Change Biol., 10, 1482-1491, 2004.

Eugster, W. and Senn, W.: A cospectral correction model for measurement of turbulent NO2 flux, Boundary-Layer Meteorol., 74, 321-340, 1995.

Foken, T.: The energy balance closure problem: An overview, Postconference workshop to the 1st iLEAPS Science Conference, Flux Measurements in Difficult Conditions, a Specialist Workshop Boulder, Colorado, USA, 26-28 January 2006.

Garcia-Herrera, R., Paredes, D., Trigo, R. M., Franco- Trigo, I.,
Hernandez, E., Barriopedro, D., and Mendes, M. A.: The outstanding 2004/05 drought in the berian peninsula: Associated atmospheric circulation, J. Hydrometeorol., 9, 483-498, 2007.

Gilmanov, T. G., Tieszen, L. L., Wylie, B. K., Flanagan, L. B., Frank, A. B., Haferkamp, M. R., Meyers, T. P., and Morgan, J. A.: Integration of $\mathrm{CO}_{2}$ flux and remotely-sensed data for primary production and ecosystem respiration analyses in the northern great plains: Potential for quantitative spatial extrapolation, Global Ecol. Biogeogr., 14, 271-292, 2005.

Gilmanov, T. G., Soussana, J. F., Aires, L., Allard, V., Ammann, C., Balzarolo, M., Barcza, Z., Bernhofer, C., Campbell, C. L., Cernusca, A., Cescatti, A., Clifton-Brown, J., Dirks, B. O.M., Dore, S., Eugster, W., Fuhrer, J., Gimeno, C., Gruenwald, T., Haszpra, L., Hensen, A., Ibrom, A., Jacobs, A.F.G., Jones, M. B., Lanigan, G., Laurila, T., Lohila, A., Manca, G., Marcolla, B., Nagy, Z., Pilegaard, K., Pinter, K., Pio, C., Raschi, A., Rogiers, N., Sanz, M. J., Stefani, P., Sutton, M., Tuba, Z., Valentini, R., Williams, M. L., and Wohlfahrt, G.: Partitioning european grassland net ecosystem $\mathrm{CO}_{2}$ exchange into gross primary productivity and ecosystem respiration using light response function analysis Agriculture, Ecosyst. Environ., 28, 121, 93-120, 2007.

Göckede, M., Rebmann, C., and Foken, T.: A combination of quality assessment tools for eddy covariance measurements with footprint modelling for the characterisation of complex sites, Agric. Forest Meteorol., 127, 175-188, 2004.

Granier, A., Reichstein, M., Breda, N., Janssens, I. A., Falge, E., Ciais, P., Grunwald, T., Aubinet, M., Berbigier, P., Bernhofer, C., Buchmann, N., Facini, O., Grassi, G., Heinesch, B., Ilvesniemi, H., Keronen, P., Knohl, A., Kostner, B., Lagergren, F., Lindroth, A., Longdoz, B., Loustau, D., Mateus, J., Montagnani, L., Nys, C., Moors, E., Papale, D., Peiffer, M., Pilegaard, K., Pita, G., Pumpanen, J., Rambal, S., Rebmann, C., Rodrigues, A., Seufert, G.,Tenhunen, J., Vesala, T., and Wang, Q.: Evidence for soil water control on carbon and water dynamics in european forests during the extremely dry year: 2003, Agric. Forest Meteorol., 143, 123-145, 2007.

Greco, S. and Baldocchi, D. D.: Seasonal variations of $\mathrm{CO}_{2}$ and water vapour exchange rates over a temperate deciduous forest, Global Change Biol., 2, 183-197, 1996.

Huxman, T. E., Smith, M. D., Fay, P. A., Knapp, A. K., Shaw, M. R., Loik, M. E., Smith, S. D., Tissue, D. T., Zak, J. C., Weltzin, J. F., Pockman, W. T., Sala, O. E., Haddad, B. M., Harte, J., Koch, G. W., Schwinning, S., Small, E. E., and Williams, D. G.: Convergence across biomes to a common rain-use efficiency, Nature, 429, 651-654, 2004.

Janssens, I. A., Freibauer, A., Ciais, P., Smith, P., Nabuurs, G. J., Folberth, G., Schlamadinger, B., Hutjes, R. W. A., Ceulemans, R., and Schulze, E. D.: Europe's terrestrial biosphere absorbs 7 to $12 \%$ of European anthropogenic $\mathrm{CO}_{2}$ emissions, Science, 300 , 1538-1542, 2003.

Jarvis, P. G., Rey, A., Petsikos, C., Wingate, L., Rayment, M., Pereira, J. S., Banza, J., David, J. S., Miglietta, F., Borgetti, M., Manca, G., and Valentini, R.: Drying and wetting of Mediterranean soils stimulates decomposition and carbon dioxide emission: The "birch effect", Tree Physiology, 27, 929-940, 2007.

Kristensen, L., Mann, J., Oncley, S. P., and Wyngaard, J. C.: How Close is Close Enough when Measuring Scalar Fluxes with Displaced Sensors?, J. Atmos. Oceanic Tech., 14, 814-821, 1997.

Kowalski, A. S., Loustau, D., Berbigier, P., Manca, G., Tedeschi, 
V., Borghetti, M., Valentini, R., Kolari, P., Berninger, F., Rannik, È., Hari, P., Rayment, M., Mencuccini, M., Moncrieff, J., and Grace, J.: Paired comparisons of carbon exchange between undisturbed and regenerating stands in four managed forests in europe, Global Change Biol., 10, 1707-1723, 2004.

Kurz-Besson, C., Otieno, D., Vale, R. L., Siegwolf, R., Schmidt, M., Herd, A., Nogueira, C., David, T. S., David, J. S., Tenhunen, J., Pereira, J. S., and Chaves, M.: Hydraulic lift in cork oak trees in a savannah-type Mediterranean ecosystem and its contribution to the local water balance, Plant Soil, 282, 361-378, 2006.

Lauenroth, W. K., Burke, I. C., and Paruelo, J. M.: Patterns of production and precipitation use efficiency of winter wheat and native grasslands in the central great plains of the United States, Ecosystems, 3, 344-351, 2000.

Liu, H. P. and Peters, G.: New equations for sonic temperature variance and buoyancy heat flux with an omnidirectional sonic anemometer, Boundary-Layer Meteorol., 100, 459-468, 2001.

Loustau, D., Hungate, B., and Drake, B.: Water, nitrogen, rising atmospheric $\mathrm{CO}_{2}$ and terrestrial productivity, in: Terrestrial global productivity, edited by: Roy, J., Saugier, B., and Mooney, H. A., Academic Press, San Diego, Calif., 123-167, 2001.

Mauder, M. and Foken, T.: Quality control of eddy covariance measurements (c: 0,1,2). CarboEurope-IP Task 1.2.2, 2004.

McMillen, R. T.: An eddy correlation technique with extended applicability to non-simple terrain, Boundary-Layer Meteorol., 43, 231-245, 1988

Miranda, P. M. A., Valente, M. A., Tomé, A. R., Trigo, R., Coelho, M. F. E. S., Aguiar, A., and Azevedo, E. B.: O clima de Portugal nos séculos XX e XXI, in: Alterações climáticas em Portugal, edited by: Santos, F. D. and Miranda, P., Cenários, impactes e medidas de adaptação. Gradiva, Lisboa, 45-113, 2006.

Otieno, D., Schmidt, M. W. T., Kurz-Besson, C., Lobo-do-Vale, R., Pereira, J. S., and Tenhunen. J.:. Regulation of transpirational water loss in Quercus suber trees in a Mediterranean-type ecosystem, Tree Physiology, 27, 1179-1187, 2007.

Palmroth, S., Oren, R., McCarthy, H. R., Johnsen, K. H., Finzi, A. C., Butnor, J. R., Ryan, M. G., and Schlesinger, W. H.: Aboveground sink strength in forests controls the allocation of carbon below ground and its [co 2]-induced enhancement, Proceedings of the National Academy of Sciences of the United States of America, 103(51), 19362-19367, 2006

Paredes, D., Trigo, R. M., Garcia-Herrera, R., and Trigo, I. F.: Understanding precipitation changes in iberia in early spring: Weather typing and storm-tracking approaches, J. Hydrometeorol., 7, 101-113, 2006.

Pereira, J. S., Chaves, M. M., Caldeira, M. C., and Correia, A. V.: Water availability and productivity, in: Plant growth and climate change, edited by: Morrison, J. I. L. and Morecroft, D., Blackwell Publishers, London, 118-145, 2006.

Rebmann, C., Gockede, M., Foken, T., Aubinet, M., Aurela, M., Berbigier, P., Bernhofer, C., Buchmann, N., Carrara, A., Cescatti, A., Ceulemans, R., Clement, R., Elbers, J. A., Granier, A., Grunwald, T., Guyon, D., Havrankova, K., Heinesch, B., Knohl, A., Laurila, T., Longdoz, B., Marcolla, B., Markkanen, T., Miglietta, F., Moncrieff, J., Montagnani, L., Moors, E., Nardino, M., Ourcival, J. M., Rambal, S., Rannik, U., Rotenberg, E., Sedlak, P., Unterhuber, G., Vesala, T., and Yakir, D.: Quality analysis applied on eddy covariance measurements at complex forest sites using footprint modelling, Theor. Appl. Climatol., 80, 121-141,
2005.

Reichstein, M., Tenhunen, J.D., Roupsard, O., Ourcival, J. M., Rambal, S., Miglietta, F., Peressotti, A., Pecchiari, M., Tirone, G., and Valentini, R.: Severe drought effects on ecosystem $\mathrm{CO}_{2}$ and $\mathrm{H}_{2} \mathrm{O}$ fluxes at three mediterranean evergreen sites: Revision of current hypotheses?, Global Change Biol., 8, 999-1017, 2002.

Reichstein, M., Falge, E., Baldocchi, D., Papale, D., Aubinet, M., Berbigier, P., Bernhofer, C., Buchmann, N., Gilmanov, T., Granier, A., Grunwald, T., Havrankova, K., Ilvesniemi, H., Janous, D., Knohl, A., Laurila, T., Lohila, A., Loustau, D., Matteucci, G., Meyers, T., Miglietta, F., Ourcival, J.M., Pumpanen, J., Rambal, S., Rotenberg, E., Sanz, M., Tenhunen, J., Seufert, G., Vaccari, F., Vesala, T., Yakir, D., and Valentini, R.: On the separation of net ecosystem exchange into assimilation and ecosystem respiration: Review and improved algorithm, Global Change Biol., 11, 1424-1439, 2005.

Rosati, A. and DeJong, T. M.: Estimating photosynthetic radiation use efficiency using incident light and photosynthesis of individual leaves, Ann. Botany, 91, 869-877, 2003.

Russell, G., Jarvis, P. G., and Monteith, J. L.: Absorption of radiation by canopies and stand growth, in: Plant canopies. Their growth form and function, edited by: Russell, G., Marshall, B., and Jarvis, P. G., Cambridge Univ. Press, Cambridge, 21-39, 1989.

Schenk, H. J. and Jackson, R. B.: Mapping the global distribution of deep roots in relation to climate and soil characteristics, Geoderma, 126, 129-140, 2005.

Shotanus, E. K., Nieuwstadt, F. T. M., and de Bruin, H. A. R.: Temperature measurement with a sonic anemometer and its application to heat and moisture flux, Boundary-Layer Meteorol., 26, 81-93, 1983.

Tang, J. and Baldocchi, D. D.: Spatial-temporal variation in soil respiration in an oak-grass savanna ecosystem in California and its partitioning into autotrophic and heterotrophic components, Biogeochemistry, 73, 183-207, 2005.

Vickers, D. and Mahrt, L.: Quality control and flux sampling problems for tower and aircraft data, J. Atmos. Oceanic Technol., 14, 512-526, 1997.

Webb, E. K., Pearman, G. I., and Leuning, R.: Correction of flux measurements for density effects due to heat and water-vapor transfer, Q. J. Ro. Meteor. Soc., 106, 85-100, 1980.

Wilczak, J. M., Oncley, S. P., and Stage, S. A.: Sonic anemometer tilt correction algorithms, Boundary-Layer Meteorol., 99, 127150, 2001.

Wohlfahrt, G., Anfang, C., Bahn, M., Haslwanter, A., Newesely, C., Schmitt, M., Drösler, M., Pfadenhauer, J., and Cernusca, A.: Quantifying nighttime ecosystem respiration of a meadow using eddy covariance, chambers and modelling, Agric. Forest Meteorol., 128, 141-162, 2005.

Xoplaki, E., Gonzalez-Rouco, J. F., Luterbacher, J., and Wanner, H.: Wet season Mediterranean precipitation variability: influence of large-scale dynamics and trends, Clim. Dynam., 23, 63-78, 2004.

$\mathrm{Xu}, \mathrm{L}$. K. and Baldocchi, D. D.: Seasonal variation in carbon dioxide exchange over a Mediterranean annual grassland in California, Agric. Forest Meteorol., 123, 79-96, 2004. 